\title{
Professor Fernando Figueira Professor Fernando Figueira
}

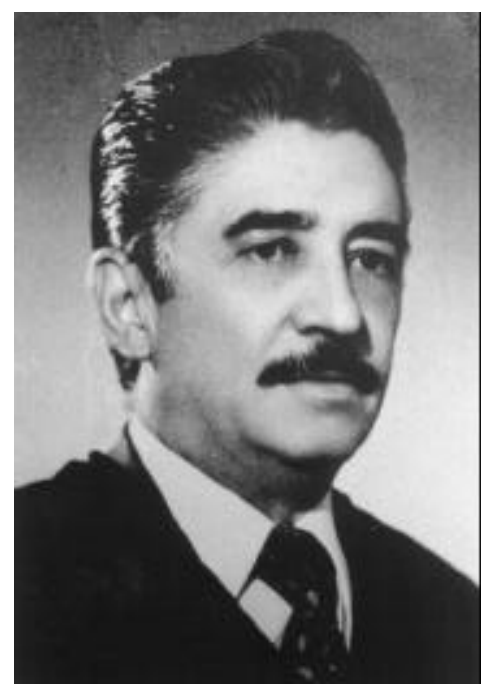

A pediatria perdeu, no último dia 1 de abril a figura exponencial do professor Fernando Figueira, médico e criador do Instituto Materno Infantil de Pernambuco (IMIP), uma das mais importantes instituições de saúde do Brasil. Falecido aos 84 anos de idade, sua obras e seus ideais, porém, são certamente perenes. Sua vida inteira dedicada ao ensino, à pesquisa na área médico-social e à assistência aos mais carentes, foi pautada pelos princípios de solidariedade, fraternidade e respeito àqueles das camadas sociais menos favorecidas.

Como médico, demonstrou sempre a consciência da importância da utilização rigorosa do saber coerente com a realidade social, econômica e cultural vivida por grande parte da população nordestina. Dizia que o exercício da medicina nunca devia subordinar-se à crueza das leis econômicas, mas ao contrário, ser regido pelas necessidades das pessoas conforme o momento histórico. Via nos olhos de uma mãe desprovida de recursos para salvar seu filho doente, um olhar acusativo das injustiças sociais.

Como professor, ensinava que, antes da medicina, o aluno deveria conhecer a população a que iria servir para, assim, poder servi-la melhor. Dizia sempre que o melhor professor na área médica, era o paciente pobre, pois às custas da sua dor e do seu sofrimento, é que os médicos construíam todo um conhecimento e uma experiência. Acrescentava ainda ser essa uma dívida irresgatável, contraída pelo médico, para com os mais pobres. Por isso, era intransigente com seus alunos quanto à exigência de respeito e de dignidade no atendimento às pessoas. Para aqueles que tendo construido o seu saber à custa dos mais pobres, e ao galgarem os degraus da pós-graduação, dirigiam este saber exclusivamente à faixa da população que podia pagar-lhes os serviços, mantinha o respeito, mas fazia suas orações para que dessem um melhor sentido às suas vidas.

Como administrador teve notável atuação. Foi um dos fundadores do Instituto de Nutrição da Universidade Federal de Pernambuco (1962), e criou a Academia Pernambucana de Medicina (1970). Presidiu a Sociedade de Medicina de Pernambuco entre 1969 a 1971. Quando Secretário de Saúde de Pernambuco (1971 a 1975), foi pioneiro na elaboração de um Plano de Saúde para o estado. Criou, ainda, a Fundação de Saúde Amaury de Medeiros (FUSAM), o Centro Integrado de Saúde Amaury de Medeiros (CISAM) e o Hemocentro de Pernambuco (HEMOPE). Reformulou o atendimento psiquiátrico no estado, implantando a triagem dos doentes e evitando hospitalizações desnecessárias.

Homem de extrema coragem, perseverança e capacidade de luta em prol dos mais necessitados, mostrou-se um verdadeiro paladino dos direitos da criança brasileira. Foi a primeira voz no Brasil que publicamente se posicionou contra a forte indústria alimentícia, ao proibir a distribuição de leite em pó nas maternidades; estavam plantadas as sementes dos programas de incentivo ao aleitamento materno. Com muita convicção e energia moral, praticou um dos primeiros gestos oficiais de desobediência civil contra a ditadura militar, ao elaborar parecer que impedia a cassação, pelo decreto lei 477, de 37 estudantes de medicina da Universidade Federal de Pernambuco no ano de 1969.

Sua maior obra, o Instituto Materno Infantil de Pernambuco (IMIP), fundado em 13 de junho de 1960, tem uma história e uma filosofia de trabalho pautadas nos mais elevados compromissos sociais. Esta instituição nasceu e se desenvolveu comprometida com a saúde da mulher e da criança carente no contexto da família e da sociedade. É uma entidade não estatal, filantrópica e sem fins lucrativos, centro de referência nacional para a assistência materno-infantil do Ministério da Saúde, e Instituição de Ensino Superior reconhecida pelo Ministério da Educação. Foi o primeiro serviço no Brasil a receber o diploma de "Hospital Amigo da Criança", outorgado pela Organização Mundial da Saúde (OMS), pelo Fundo das Nações Unidas para a Infância (UNICEF) e pelo Ministério da Saúde. O seu complexo hospitalar é atualmente composto por mais de $25.000 \mathrm{~m}^{2}$ de área construída onde se realizam mais de 350.000 atendimentos anuais. Desenvolve ainda um intenso e permanente trabalho de 
extensão comunitária nas áreas de assistência e ensino em oito comunidades de baixa renda da região metropolitana do Recife, beneficiando cerca de 70.000 pessoas. Quase 1.000 profissionais participaram no ano passado dos programas de graduação ou pós-graduação em diversas áreas do setor saúde. Mantém um Núcleo de Pesquisa com vários projetos nacionais e internacionais e edita, atualmente, a Revista Brasileira de Saúde Materno-Infantil.

Esta é a obra de Fernando Figueira. Personalidade impar, sempre batalhou no resgate da enorme dívida social, manifestada nos desajustes e contrastes do processo saúde/doença. Ao lado de Octávio de Freitas, Amaury de Medeiros e Josué de Castro, deu certamente uma das as maiores contribuições à medicina de Pernambuco no século XX.

João Guilherme Bezerra Alves

Revista Brasileira de Saúde Materno Infantil / Brazilian Journal of Mother and Child Health

Editor chefe 